Article

\title{
Two Linguas Francas? Social Inclusion through English and Esperanto
}

\author{
Federico Gobbo ${ }^{1, *}$ and László Marácz ${ }^{2,3}$ \\ ${ }^{1}$ Amsterdam Center for Language and Communication, University of Amsterdam, 1012 VB Amsterdam, The Netherlands; \\ E-Mail: f.gobbo@uva.nl \\ ${ }^{2}$ Faculty of Humanities, University of Amsterdam, 1012 CX Amsterdam, The Netherlands; E-Mail: I.k.maracz@uva.nl \\ ${ }^{3}$ Department of International Relations, L. N. Gumilyov Eurasian National University, 010000 Astana, Kazakhstan \\ * Corresponding author
}

Submitted: 19 September 2020 | Accepted: 5 November 2020 | Published: 14 January 2021

\begin{abstract}
New forms of mobility presuppose a technological factor that frames it as 'topological proximity,' regardless of the nature of the mobile agent (human being, robot ware, animal, virus, digital object). The appeal of the so-called linguas francas is especially evident in human beings showing high propensity to move, i.e., motility. They are usually associated with transnational communication in multilingual settings, linguistic justice, and globalization. Paradoxically, such global languages foster mobility, but, at the same time, they may hinder social inclusion in the hosting society, especially for people in mobility. The article compares English as a lingua franca and Esperanto in the European context, putting together the linguistic hierarchy of transnational communication (Gobbo, 2015) and the notion of linguistic unease, used to assess sociolinguistic justice (lannàccaro, Gobbo, \& Dell'Aquila, 2018). The analysis shows that the sense of belonging of their respective speakers influences social inclusion in different ways. More in general, the article frames the linguistic dimension of social inclusion in terms of linguistic ease, proposing a scale suitable for the analysis of European contexts.
\end{abstract}

\section{Keywords}

Esperanto; hyper-place; lingua franca; linguistic easiness; linguistic justice; mobility; onlife; social inclusion; sociolinguistic justice

\section{Issue}

This article is part of the issue "Social Inclusion and Multilingualism: The Impact of Linguistic Justice, Economy of Language and Language Policy" edited by László Marácz (University of Amsterdam, The Netherlands / L. N. Gumilyov Eurasian National University, Kazakhstan) and Zsombor Csata (Babeș-Bolyai University, Romania / Hungarian Academy of Sciences, Hungary).

(C) 2021 by the authors; licensee Cogitatio (Lisbon, Portugal). This article is licensed under a Creative Commons Attribution 4.0 International License (CC BY).

\section{Introduction}

Humanity is currently facing the greatest challenges of urbanization in its whole history. According to the United Nations Population Fund, more than half of the world population will live in global cities by 2030 . The increase of urbanization raises opportunities (such as economic well-being) and simultaneously raises problems (such as social inequality). However, the existing literature on this topic lacks clarity regarding the role played by technology in re-defining topological proximity. In fact, the pervasiveness of ICTs eventually blurs the distinction between reality and virtuality. In sharp contrast with
Marg Augé's concept of non-places, Lussault (2017) talks about hyper-places, where dimensions of real and virtual locality co-exist. Hyper-places exist at the same time locally and globally, and this means that what happens there has repercussions in all dimensions in their topological proximity. An example of this is Times Square, which is local (place in New York), national (within the USA) and global: A demonstration held there reaches a different audience according to other parts of the world, e.g., Paris, Tokyo, Dubai. In other terms, what happens collectively in a hyper-place influences not only the local space but also and mainly the connected hyper-places, re-defining the concept of human geography. The world 
did become neither 'flat' nor 'liquid,' i.e., a supposed homogeneous isotropic space, but on the contrary its topology is more complex than ever. For instance, there are now digital divides, connection gaps as well as information highways.

What does it mean to be close, under the emic perspective of a (human) agent? Basically, proximity is defined by the kind of information that can be accessed by the agent. Houtkamp $(2018,2020)$ argues that motility, i.e., the propensity to move to a new country, is predictive of actual behavior with reasonable accuracy. In terms of language attitudes, if I am from country $X$ and I want to move to country $Y$, it is probable that I would look for digital resources about the national language(s) of country $Y$ before the physical move even occurs. Most analysts, for instance Lussault (2017), are in agreement that mobility cannot be limited to the physical act, transport and logistics. In particular, mobility is a factor regardless of the nature of the mobile agent: human being, robot ware, animal, virus, digital object, etc. However, this essentialist vision conceives agents as completely independent according to their nature, while in many cases they are not: For instance, many human agents carry digital agents with them most of the same time, as they constantly transmit information, mainly through mobile devices.

In other words, most of the human population does no longer live purely in a real world, as phones and similar devices, even if not actively engaged with them, constantly put them online and offline at the same time, i.e., onlife (Floridi, 2015). Even the anthropic environment where we live is more and more shaped in order to accommodate the needs of ICTs-for instance, think about domotics. On the other hand, scholarly literature reflecting on this hyperconnected world rarely takes into account how much language choices impact the propensity to move.

\section{Two Global Languages in Comparison: English and Esperanto}

This article explores the issue of complex linguistic diversity in the choice of using global languages, such as English and Esperanto, and the consequences on the notion of lingua franca, and how it influences social inclusion in an onlife world. Two fundamental dimensions in the design of public policies aiming in managing linguistic diversity should be considered: mobility and social inclusion. Grin et al. (2018) show that the academic discourse around the interplay between mobility and social inclusion has been fragmented across disciplines for too long and call for more in-depth and coherent analyses. In particular, the role of languages as indicators is still underestimated as an indicator of social inclusion and is currently under scrutiny from a variety of angles. In order to illustrate our argument, which is mainly theoretical, we will refer to the European context only in general terms: Case study analyses in concrete settings are left as further work.
One of the clearest phenomena associated with globalization is the globalization of languages (Steger, 2003, p. 72). Where communities are no longer characterized by shared primary socialization nor by a common native language, Seidlhofer (2009, p. 39), for instance, argues that the need for a lingua franca is growing. However, situations may differ greatly depending on the situation and place in the world, therefore we need to analyze their linguistic panoramas in their complexity. Such facts make us rely on the concept of complex linguistic diversity described by Kraus (2012, p. 13) as follows: Complex linguistic diversity is:

Meant to come to grips with a constellation in which cultural [and linguistic aspects], identities and social cleavages overlap and intertwine in manifold ways... [pointing] at a social and political context in which diversity has become a multidimensional and fluid phenomenon.

Thus, complex linguistic diversity is tackled in terms of independent linguistic layers, each one serving a specific purpose, but both in terms of mobility and social inclusion (Marácz, 2014). Paradoxically, global languages, with their promise of fostering mobility may ultimately impact social inclusion in the hosting society.

Hülmbauer, Böhringer, and Seidlhofer (2008, p. 27) define the concept of a lingua franca as a language that acts as a bridge between persons who share neither a common native tongue, nor a common (national) culture, and for whom the lingua franca is the chosen foreign language of communication. According to the definition presented above, such a definition usually implies that a lingua franca is also a global language. Strictly speaking, a lingua franca should be the neutral language involved in communication with speakers that are not familiar with each other's languages. The adjective 'neutral' here, which renders 'franca' as in 'free,' is essential: The language should belong to none of the speakers involved in communication. When native and non-native multilingual interaction is involved, it would be better to speak of a 'vehicular language,' in the case of English but not only. However, we will refer to this variant as a lingua franca in the remainder of the argumentation. We compare a variant of English functioning as a lingua franca (Jenkins, 2014; Seidlhofer, 2011) and Esperanto, in order to illustrate our discussion on the linguistic dimension of social inclusion.

\subsection{English as a Lingua Franca}

The spread of English at a global level after the fall of USSR and the end of the Cold War did not get unnoticed. Pennycook (2017) identifies and discusses the three main paradigms found in the literature that analyze the position of English vis-à-vis the other languages in a given multilingual context: the Circle model of World Englishes (since at least Kachru, 1992); linguistic imperi- 
alism (since at least Phillipson, 1992); English as a lingua franca (ELF; see at least Seidlhofer, 2011). Let us discuss ELF in more detail.

The definition of globalization covers these key qualities, including world-wide cultural homogenization, migration, foreign language learning and tourism, Internet and international scientific publications. Apart from the number of declining languages, there is some consensus on the growing global significance of a few set of languages over all the others, particularly English, Chinese and Spanish. Commentators stress the power of the Anglo-American culture industry to make English the global lingua franca of the 21st century. This lingua franca has been labeled ELF (Jenkins, 2014, pp. 39-40; Seidlhofer, 2011, p. 16). Crystal (2004, p. 40) already depicted the situation that started to emerge in the early years of the new millennium as follows:

The situation is unprecedented, with more people using English in more places than at any time in the language's history, and unpredictable, with the forces promoting linguistic identity and intelligibility competing with each other in unexpected ways. For those who have to work professionally with English, accordingly, it is a very difficult time. After all, there has never been such a period of rapid and fundamental change since the explosions of development that hit the language in the Middle Ages and the Renaissance.

Seidlhofer (2009, p. 48, emphasis by the authors) identifies as main features of ELF "its characteristic variability, hybridity and fluidity." Jenkins, on the other hand, advocates for:

The legitimate appropriation of the English language by its majority expanding circle users [by definition, non-native], together with whatever diversity and hybridity suited their own purposes rather than the purposes of inner circle speakers. (Jenkins, 2014, pp. 39-40, emphasis by the authors)

Based mainly on Jenkins (2006, 2014), Hülmbauer et al. (2008), Seidlhofer (2009, 2011), Hülmbauer (2009), and Marácz (2018), we argue that hybridity entails three consequences on ELF that impact social inclusion.

First, on an individual level, ELF is seen as a flexible mode of intercultural communication rather than a fixed code (Marácz, 2018, pp. 102-103), showing as fundamental traits variability, hybridity and fluidity. In other words, it is negotiated and individually shaped by its users according to the needs of the situation, in which effectiveness of communication rules over correct grammatical usage. It can potentially take any form and can potentially fulfil any function. Ultimately, this is determined by accommodative strategies typically characterized by plurilingual elements and the emergence of new patterns of lexical elements and grammar.
Second, on a group level, ELF is supposed to integrate all speakers, including native speakers. There are more ELF speakers-and more interactions among themthan native speakers of English. The group of users is not fixed but scattered. In other words, instead of forming a speech community or a community of practice, which defines itself through ELF, speakers using ELF rely on a pragmatic and situational basis, possibly with no face-to-face interaction. It is a matter of research in what sense ELF is associated with a new linguistic global identity instead of the old ethnic identity; in particular, the relevance of the society where ELF is used cannot be underestimated and should be taken into account in order to understand its impact (Gobbo, 2015).

Third, on a more general level, ELF appears in different forms because it fosters an intercultural mode, combining the cultural background of English-speaking countries with other lingua-cultural backgrounds and their interplay. In Europe, ELF has become an essential component of multilingual contexts in general and of Europeans' plurilingual repertoires in particular. These key qualities of ELF discussed above most strikingly illustrate the hybrid nature of ELF, i.e., it appears in an intercultural context, it has no standard code and it is affected by different lingua-cultural backgrounds and their interplay. ELF constantly relates to other languages in the sense that it is ever-changing within the multilingual contexts in which it is found. Influences of other languages are a natural and crucial characteristic of ELF at all linguistic levels, i.e., phonological, morphological, syntactical, lexical and pragmatic (Hülmbauer et al., 2008, p. 29). Jenkins (2006, p. 140) refers to these native language influences as "bilingual resources." Hence, these first language interactions on ELF involves communicative strategies such as the exploitation of parallel structures in different L1s, code-switching techniques, intercomprehension, and so on, may be universal, i.e., languageindependent (Hülmbauer et al., 2008, p. 32). Much of the linguistic research in the field of ELF takes these linguistic strategies into account.

The functional motivation of ELF makes it impossible to elaborate on a standard code, for languages are unstable, always in flux, react to outer circumstances and conditions (see Jenkins, 2006; Jenkins, Cogo, \& Dewey, 2011, pp. 283-284). If a language spreads particularly wide, and fast and it is confronted with massive language contact it will also change fast. According to their advocates, this functional motivation of ELF yields hybridization comparable to pidginization and creolization which are well-documented instances of hybrid language creation. However, studies on pidgins and creoles show that the colonial and post-colonial contexts in which pidgins emerge and creoles develop are radically different in comparison to the onlife world we are living in today (as illustrated above; for onlife see Floridi, 2015), therefore their respective linguistic phenomena are different indeed. In particular, the technological factor fosters language use in written form much more than before, espe- 
cially using non-standard graphization (for English see Crystal, 2008).

We argue that the onlife world is radically different, and therefore that it cannot be compared to the old colonial contexts where pidgins emerged. According to Jenkins and collaborators, ELF is occupying a "third space" between two further language variants of English (Jenkins, 2006, p. 155), including English as a native language and English as a foreign language, that is a target language with a standard code for non-native speakers of English. However, eventually Jenkins et al. (2011) and Jenkins (2014) find empirical evidence of such 'third space' mainly in two specific domains, i.e., academia and business, where it leads to consequences in language teaching and acquisition. Eventually, even the proponents of ELF admit that it is only used in a restricted number of settings.

The question arises what the position of ELF is within Europe, a continent that has been historically characterized by linguistic diversity, where major languages such as English, French, Spanish played a crucial role in colonialism. In the history of European multilingualism and the use of communication languages, i.e., so-called linguas francas, by speakers with a different mother tongue have been changing over time. Most probably ELF will not be sufficient to cover all the communicational settings, as it seems to work only in domain-specific settings; therefore, further language resources are required in order to cope with the complexity of multilingual settings found across the continent. At present, this linguistic diversity of Europe is supported by the EU's language policy facilitating the practice of multilingualism at all tiers of governance.

The position of ELF in a multilingual Europe is not that strong as it is generally perceived. It is true that ELF or a European variant of it has made an important expansion in that it is used more frequently than German or French as a lingua franca. Although, German has the highest number of speakers, i.e., 16 percent of the population, only 11 percent of the total speakers of the EU know German as a foreign language, that is 27 percent in total. English is used most commonly in the EU with 13 percent native speakers and 38 percent foreign speakers, in total 51 percent. French is the third frequently spoken language in the EU, namely 12 percent native speakers and 12 percent foreign speakers, that is 24 percent in total (Directorate-General for Communication, 2012; we use the terms 'native speakers,' 'mother tongue' and 'foreign language' as they are used in the Eurobarometer, even if they are social constructions made up to establish the nation-state after the Treaty of Westphalia and in particular during Romanticism; see Bonfiglio, 2013, 2010; Myhill, 2006).

Some commentators are worried that ELF seems to endanger the vitality of other European languages as vehicular languages. In an article summarizing this problem, Seidlhofer, Breiteneder, and Pitzl (2006, p. 8) admit: "This situation is obviously problematic. The need for a common means of communication is in potential conflict with the ideals of societal multilingualism and individual plurilingualism." The authors distinguish two major types of communicative situations in which English serves as:

A direct mediator between participants in a discourse that would otherwise have to rely on translation or a third party....The current role of English in Europe is thus characterized by the fact that the language has become a lingua franca, a language of wider communication, and that it has entered the continent in two directions as it were, top-down by fulfilling functions in various professional domains and, simultaneously, bottom-up by being encountered and used by speakers from all levels of society in practically all walks of life. (Seidlhofer et al., 2006, p. 5)

It is in situations of the first type that the employment of English subjects, the participants to the norms of a native like competence will be relevant: conversations with natives, international conferences with participation of native speakers, English-as-foreign language instructional contexts of various kinds, and so forth. But there is also the usage of English in 'informal settings' as a vehicle of communication among groups of non-native participants, as a lingua franca in a strict sense. In this type liesaccording to Seidlhofer et al. (2006)-the basis for the genesis of new varieties of English which are 'endonormative,' with rules of communication of their own right. Undoubtedly, the respective source languages of the non-natives can be seen as reflected in the usage of ELF. In this sense, one speaks of 'Englishes.' But it would "seem premature to ask questions about the degree to which English as a lingua franca in Europe can be regarded as an actual variety, i.e., Euro-English in any meaningful sense" (Seidlhofer et al., 2006, p. 21). In sum, we argue that, while playing a role as a domain-specific communication strategy, ELF will not be the ultimate solution to manage Europe's multilingual realities.

In the case of ELF, hybridity consists in the emergence of various variants of English across the world, that do not rely on the distribution of British or American norms and standards. Thus, there are no firm norms associated with ELF as the interferences of the native tongues of speakers of ELF are present all over the place in various transient forms, hindering the process of 'endonormation' mentioned above. Hence, there are as much varieties of such Englishes as the communicative situations that are even extrapolated. What the speakers of ELF have in common is that they rely on a common set of accommodation and communication strategies, which are actually found in many other linguistic contexts involving non-native speakers, regardless of the language involved (Marácz, 2018, pp. 102-103).

Most of the discussion in the literature behind the feasibility of the expression 'lingua franca' questions the position of native speakers. In particular, on the one hand, native speakers are targeted as being in a posi- 
tion of unfair advantage. On the other hand, what 'native speakers' exactly means is often unclear, especially in the case of early bilingual speakers (see Sorace, 2004), and in the case of 'new speakers,' emerging in language revitalization programs of minority languages (O'Rourke, Pujolar, \& Ramallo, 2015).

In the essentialist view that English is a lingua franca tout court, English natives are questioned as such. In such a view, English does not belong to any specific group and therefore it is global and free ('franca'). On the contrary, under an anti-essentialist view, the question of 'nativeness' is solved in emic vs etic terms: Even multilingual societies per se challenge the etic, objective, existence of native speakers, on the other hand the institutions devoted to keep the prestigious role of linguistic norm high-in the case of English, a good example is the British Council-are not diminishing their leading role, quite the contrary. From an emic, subjective, point of view, the normative register of a language is usually paired with the prototypical monolingual speaker. In other words, native speakers are identified as the gatekeepers of the linguistic norm.

Within this second view, the expression 'lingua franca' becomes more of a fluid set of strategies of linguistic accommodation where native speakers (in the emic perspective of the agents' judgement) are not present, and therefore non-native speakers feel free to use language contact strategies to make themselves understood, going across the boundaries set by the normative register. However, such a strategy is volatile, as sooner or later the situation will involve either a shift to a formal register or the direct involvement of native speakers, and then the 'magic of freedom' in using ELF suddenly vanishes.

\subsection{Esperanto as a Lingua Franca and the Question of Nativeness}

It is interesting to notice that the path Esperanto is going through is reversed in many aspects. Since its launching as Zamenhof's language project in 1887, Esperanto was conceived as a truly lingua franca for international communication, not being attached to a particular group of people but belonging-at least according to its mainstream ideology - to the whole world (Gobbo, 2017). From a typological point of view, it is a contact language between the three main language families of Europe: Romance, Germanic and Slavic. Moreover, it borrows some features from Ancient Greek and Latin. On a deep level, e.g., phonological, Esperanto seems to be more influenced by Slavic languages, in particular Russian and Polish (Lindstedt, 2009; Marcialis, 2011). On the other hand, on a surface level, e.g., lexical, Esperanto shows a predominance of Latin and Latinate roots (Gledhill, 2000). This delicate equilibrium is stable thanks to a small but clear set of morphological rules fixed by its launcher Zamenhof (1905) that formed the boundaries of language variation in the crucial years of the establishment of the community of practice, from the first
World Esperanto Congress (1905) until Zamenhof's passing in 1917. It is important to underline the fact that Esperanto succeeded in becoming a living language, even if its linguistic sources are highly heterogeneous thanks to existence of such norms, as they guarantee mutual understanding among Esperanto speakers from different backgrounds and therefore they are the rails that permit anybody to be included in the Esperanto community, if desired.

This is very different from the concept of 'hybridity' carried out as a crucial feature of ELF. In the case of Esperanto, 'endonormation' is guaranteed by language planning of its core features. In fact, Zamenhof fixed the rules of the core features while leaving a certain amount of freedom in how to expand the vocabulary according to needs that change across time and context, in order to foster the use in as many domains as possible. In sum, we argue that it is not the absence of rules that guarantees mutual understanding in transnational communication but on the contrary their presence: Esperanto is a living proof of that.

It is without any doubt that Esperanto speakers in many cases show a strong degree of loyalty to their adopted language, as they feel it as a part of their identity (Fiedler, 2006, p. 76). If their language loyalty is very high, they may choose to use the language within the family, traditionally the most conservative domain in terms of language loyalty and identity (see Corsetti, 1996; Fiedler, 2012; Lindstedt, 2010). The existence of 'denaskismo' has been regarded as an argument against Esperanto, which goes as follows: If there are native speakers of Esperanto, then this language is no more international and neutral because it belongs to a kind of pseudopeople. In the remainder of this section we are going to explain why 'denaskismo,' at least in its current form, is no threat to Esperanto as a lingua franca.

First of all, it is important to note that people growing up using Esperanto are not 'native' speakers stricto sensu, as no monolingual Esperanto speaker ever existed. Esperanto is always found in multilingual contexts, as there is no existing country of 'Esperantoland' in which monolingual first speakers of Esperanto use the language as their main mean of communication in their daily aspects of social life, and it never has been. In particular, Esperanto families always speak at least the language of the hosting society, and not rarely and at least an additional language is present in the respective repertoires of family members. This means that Esperanto is never the strongest language in bilingualism, as the society outside the family domain-most notably at schools in the case of children-uses other languages.

However, it is true that from the emic perspective, family speakers resemble certain traits of standard 'nativeness,' because Esperanto is acquired 'naturally,' 'from the cradle.' The sociolinguistic profile of the Esperanto speakers illustrated by Caligaris (2016), although limited in scope, shows that such speakers tend to have different language attitudes than the rest of 
the Esperanto speaking population, which justifies their treatment as a separate subgroup. Moreover, non-family speakers have polarized opinions towards them, either very positive (the majority) or totally negative (a fierce minority). Another important fact is that Esperanto families are still a tiny minority of the total population. The majority of the scholars in the field estimate approximately 1,000 family speakers on 100,000 active and passive Esperanto speakers worldwide (Lindstedt, 2010). An interest in forming stable couples of Esperanto speakers seems to be growing, and in such cases speaking Esperanto to the possible future children is at least considered an option (Caligaris, 2016). However, we would need longitudinal studies to confirm such attitude with more robust data. What is absolute certain is that, so far, there is no village or settling where Esperanto families want to live as a stable community in the sense of a 'small world apart.'

Esperanto family members, as all other Esperanto speakers, live many fundamental parts of their everyday lives-such as grocery shopping, gas getting, going to the doctor or the lawyer, or paying taxes-outside the Esperanto reality. Moreover, what Esperanto family speakers lack in order to be considered native speakers tout court languages is an authoritative role: They do play no special role in keeping and developing the normative register and the process of standardization. In this respect, they resemble more 'new speakers' of lesser-used languages after successful revitalization programs, as illustrated and discussed by Jaffe (2015). Anecdotical evidence via participant's observation by one of the authors suggests that not all family speakers are fluent in Esperanto and some of them show non-standard traits in their idiolect; unfortunately, there is no reliable empirical research to corroborate this evidence in more stable terms. In sum, their 'nativeness' is more an appealing metaphor for many Esperantists in order to reinforce their language loyalty: Family speakers are an argument arguing for Esperanto becoming a 'normal' language, whatever that means, as Esperanto is still contested as being a full-fledged language, in spite of its empirical reality as a living language.

Astori (2016) proposes to frame the Esperanto community as a kind of nation, as it shows some traits similar to the Deaf community where members' origins are far less important than the fact of being Esperantist/Deaf, both being transnational identities (for a recent account of the latter see Leigh \& O'Brien, 2019). Is there really an 'Esperantohood' similar to Deafhood? We argue that, whatever the similarities, there are fundamental differences as well: Most strikingly, there is no issue of hearing and orality at stake in the case of Esperanto, unlike the case of the Deafhood. Moreover, ideologies of sign language revitalization show different dimensions that are very specific of sign languages and are not easily applicable to spoken languages, Esperanto included. Such dimensions include: intergenerational transmission, representation, language shift, new signers and documenta- tion (Snoddon \& De Meulder, 2020). This proposal shows that the debate on the Esperanto identity is still open. We will now take a standpoint in relation to the dimension of social inclusion.

In conclusion, even if some Esperanto speakers argue for being a 'kind of' nation, stressing out their specialty, the Esperanto community of practice keeps important characters of genuine internationality, general openness towards any non-discriminatory ideology, and, above all, non-ethnicity. Consequently, anybody is welcome to join this worldwide community, regardless of ethnicity, nationality, religion, sexual orientation and other sociological variables, which is why it should not be treated as a Gemeinschaft, i.e., a speech community stricto sensu, but a community of practice. For this reason, we argue that, in terms of lingua franca use, Esperanto is much more inclusive than English, as the illustration of the role of their respective 'native speakers' have shown. In this respect, Esperanto should be given preference as a lingua franca for the norms, and standard, the lack of hybridity and native speakers will result into social inclusion, as we will show in the next sections.

\subsection{The Paradoxes of English and Esperanto as Linguas Francas: Language Prestige and Social Inclusion}

If we look at English and Esperanto as linguas francas in comparison to each other, we find opposite and somehow complementary paths in their respective language ideologies. In the case of English, there is a tension between the territories where English clearly belongs, starting from England, and its further use in the rest of the world, because of its global spread, which ultimately challenges the status of English native speakers up to the point of putting in question the existence of an ethnicneutral variety (the so-called ELF) in terms of feasibility. In the case of Esperanto, its contemporary sociolinguistic reality, which shows a firm vitality but limited in numbers, is shifting its language representation from an original ethnic-neutral language by definition to the emic representation of Esperantists as a kind of minority, as if speakers form a 'pseudo-nation' or 'quasi-people'; however, such claim seems to lack objective validity, as we have seen in Section 2.2 (see also discussion in Gobbo, 2017). Moreover, as argued in Section 2.1, on ELF is a variant of English that does not possess any explicit stated norms and standards. This means that ELF is a flexible variant of English, ever-changing and accommodating all the times to a new linguistic environment display a set of linguistic hybridity. Most importantly, whenever native speakers of English participate in ELF communicative events, their de facto authority impede social inclusion, if not leading to social exclusion.

Gobbo (2015) applies Calvet's (2006) hierarchy of language prestige in the context of transnational communication, in other terms all the contexts where participants in the communication are non-native, i.e., there is no speaker who can claim ownership or special author- 
ity on the language in use. Such use of the linguistic medium as a transient lingua franca, i.e., following the non-essentialist views already presented in the previous section, may be applied in principle to any language: international, super-national, national or sub-national. An example of the latter case is the situation where two migrants in Catalonia choose to use their Catalan learning varieties (interlanguages, starting from Selinker, 1972) instead of Spanish; their language choice signals their will to be included in the Catalonian society, regardless of their proficiency. Interestingly, Caligaris (2016) shows that Esperanto may play a similar role in the eyes of some of its speakers. In other words, analogously to many minoritized languages, in general Esperanto has a very high prestige among its speakers (emic perspective) and a very low prestige outside (etic perspective), often being contested because of its 'artificial' origin. This is reflected in its peculiar position in its digital presence: Unlike most other lesser-used languages, which suffer the digital language divide (Soria, 2016), Esperanto is relatively in a good position. For instance, its Wikipedia is relatively good, both in quantity and in quality, Facebook users may enjoy the interface in the language, and many Esperanto e-books may be purchased via major sellers. If we apply the Digital Vitality Language Scale by Ceberio Berger, Gurrutxaga Hernaiz, Soria, Russo, and Quochi (2018), Esperanto positions itself at least as developing, with some domains definitely vital. A detailed application of such scale to Esperanto would require another article and therefore it is left as a further direction of research. For the purposes of this article, it suffices to note that the position of Esperanto is relatively strong for a lesser-used language, and such positioning eventually reinforces the opportunities in learning the language through digital technologies, eventually fostering mobility.

\section{Linguistic Unease and Social Inclusion}

The survey on linguistic justice by Alcalde (2018) shows that Esperanto forces us to think again on an effective modelling for linguistic justice that takes into account both mobility (in every form: potential, i.e., motility, and actual; traditional and onlife), and social inclusion. lannàccaro et al. (2018) stress the importance of an analytic description of the repertoire of speakers following certain parameters, in order to assess the power rela- tions between groups in a given society reflected in their language choice, which lead to the introduction of the notion sociolinguistic justice in the ongoing discussion in the literature of linguistic justice. For this purpose, the individuation of linguistic unease is crucial in assessing sociolinguistic justice, which functions as a predictive indicator of the degree of inclusion in a given social context. A word apart should be devoted to the notion of Wunschsprache, literally 'language of desire,' indicating that language that does not belong to the members of the given speech community, but nonetheless has high social prestige being the point of reference of an idealized society taken as a model to follow. In general, Wunschsprachen are either international or supernational languages such as English or Standard German.

Most discourse around linguas francas in general and English in particular underlines the role played by the Wunschsprache, to the detriment of the role played by other languages in use, and in particular by the high variety of the in-group code. In many contexts across Europe such a standardized code was (re)defined during the second half of the past century. Some examples are: neostandard for Italian, Algemeen Beschaafd Nederlands for Dutch, Hochdeutsch for German and so on. On the level of national inclusion, the mastery of standardized codes guarantees an adequate social inclusion, drastically reducing linguistic unease in most relevant situations of societal life. An exception is the situation in German-speaking Switzerland, where the main in-group code is not the high variety but Swiss German. Table 1 shows the role played by codes, i.e., varieties of languages, in respect to social inclusion, which is valid in most European contexts.

In a given society, codes that foster social inclusion are labeled in-group. The high variety corresponds in many contexts with the standardized form, which is used in most formal situations, such as filing a request to a public officer, or asking a question to a teacher in a public school. Failing to master the high variety may lead to difficult situations, but paradoxically it is the mastering of the low variety that guarantees the support of the social network in informal situations. The low variety could be a dialect of the national language or a completely different language, e.g., a non-contested regional and minority language. Feeling uncomfortable with the low varieties hinders social inclusion, as the speaker does not 'belong

Table 1. The scale of linguistic unease and social inclusion in European contexts.

\begin{tabular}{cll}
\hline Level & Position in social inclusion & Relevant languages in the repertoire \\
\hline 1 & strong social inclusion, leading position & all in-group codes + Wunschsprache \\
0 & adequate social inclusion & all in-group codes \\
-1 & unease in formal situations & high variety of in-group codes \\
-2 & unease in in-group situations & low variety of in-group codes \\
-3 & out-grouped, respected & Wunschsprache (in-group codes) \\
-4 & out-grouped, severe & other codes (no in-group, no Wunschsprache) \\
\hline
\end{tabular}

Source: Original elaboration of Gobbo and Alcalde (2016). 
to us'; this may also happen in the case of compatriots moving in a different region of the same country, as their low variety differs from the one used by the locals.

Wunschsprachen may or may not foster social inclusion: in the first case (strong social inclusion; level: 1), they are like the cherry on the cake, strengthening an already unproblematic position guaranteed by the mastering of the in-group codes; in the second case (respected out-grouping; level: -3 ), such puts its speaker into a distinct bubble, perhaps a luxury one, but still a bubble, where no consistent contact exists with the hosting society except for very practical needs. The global expansion of English makes it a Wunschsprachen in many societies in the world, as it is often associated with prestige and power; the point is that the Wunschsprache should be recognized as such not only by the speaker but by the hosting society as well. For this reason, Esperanto is a peculiar case study: in fact, it plays the role of the Wunschprache for most of its speakers, who associate positive values to the language-for instance, being 'easy' to learn, 'logical,' and so on. However, most people in most societies across the world not only do not master it but they may even know nothing about it at all, so it is rubricated as an 'other' code, i.e., a language that does not foster in-grouping nor give any apart prestige in using it.

In spite of not belonging to any hosting society in particular, Esperanto may increase the motility, i.e., the inclination to move in that hosting society, especially while planning or setting the first steps there. In fact, the strong level of language loyalty among Esperanto speakers and their language ideology in practice gives the people in mobility a privileged access to these nationals who speak Esperanto who would be willing to be intercultural mediators with the newcomer. The prototypical Esperanto speaker in mobility will check the existence of language fellows living in the target destination as a way to reinforce its Esperanto network abroad as well as having a local ready to act as intercultural mediator with the hosting society. Anecdotical evidence made via a semistructured interview shows that, for example, an Italian Esperanto young lady finding a job in Bratislava will most probably have the support of the local Slovak Esperanto community and therefore her motility to accept such a job position will increase a lot thanks to the presence of a relatively relevant community of Esperanto speakers there. In other words, Esperanto may play the role of reducing linguistic unease, i.e., reducing the inadequacy of the speaker in mastering the linguistic needs, especially of the high variety code.

The presence of teachers in general and language teachers in particular in the Esperanto community seem to be relevant, even if there are no longitudinal studies on that so far (for the early period see Garvía, 2015; for a recent fieldwork see Caligaris, 2016). A hypothesis may be that Esperanto becomes the language of instruction of the high variety of the newcomer in the hosting society, so to reduce linguistic unease to an acceptable level (level: -1 ), especially if the target language is not so strong to have material for second-language learning ready off the shelf. More empirical research is needed to confirm or confute such a hypothesis.

We argue that in terms of fostering social inclusion English and Esperanto as linguas francas are very different. The limit of the literature advocating for ELF as the main 'solution' to multilingual contexts consider only the positive case where ELF is part of a repertoire, which includes the codes necessary for social inclusion in the hosting society (level: 1) while they do not consider the respected but out-grouping situation when such codes are absent (level: -2 ). Of course, the prestige of English in many societies at least guarantees being respected; the total ignorance of any language which is somehow relevant in the hosting society brings the unavoidable consequence of being severely cut out from the hosting society (level: -4). This latter situation should be avoided at any cost. Empirical evidence shows that because of its regularity a productive level of Esperanto can be acquired in a relatively short time, therefore it seems to be a good investment in increasing motility to all the parts of the world where there is a presence of Esperanto speakers.

\section{Conclusion}

Languages play an important role in analyzing societies in general and their respective modalities of social inclusion, in particular in reducing linguistic unease. In this article, we have given our contribution of their role in social inclusion. In particular, a relevant part of the literature focuses on the role played by linguas francas in general and by ELF in particular. However, such emphasis can lead to the risk of losing sight, as the societal linguistic repertoire of a given society plays a role in social inclusion, and that is not only considering the English language. In particular, the instable character of ELF, due to its hybridity and lack of normative standardization, as illustrated above, puts it as a valid solution to be used only for specific domains that generally pertain the high strata of the society, such as academia and international business.

We argue that, even if it is lesser-used, Esperanto has the intrinsic characteristics of being more apt for the role of lingua franca, it having a solid established norm that at the same time permits a good level of freedom in the lexical choices and general use. Moreover, in the case of Esperanto, there is no special group that may claim special authority on such normative standards (even not family users), unlike the case of English, where the role of native speakers should not be underestimated. Therefore, without considerations of power imbalance, under the perspective of fairness, Esperanto is more suitable over English in playing the role of lingua franca. Of course, the situation could change if Esperanto would be in use in considerable numbers in specific areas of the world, acquiring a territory, such as the EU. However, this is matter of speculation. In addition to that, we have pre- 
sented a model that helps tackling situations of complex linguistic diversity that may be found across Europe, suggesting directions in designing adequate language policies fostering social inclusion as a whole.

\section{Acknowledgments}

We acknowledge the contribution of the anonymous reviewers for their many comments and suggestions.

\section{Conflict of Interests}

The authors declare no conflict of interests.

\section{References}

Alcalde, J. (2018). Linguistic justice: An interdisciplinary overview of the literature. In M. Gazzola, T. Templin, \& B. A. Wickström (Eds.), Language policy and linguistic justice (pp. 65-149). Cham: Springer.

Astori, D. (2016). Definire una minoranza sociolinguistica: Dalle lingue segnate a quelle pianificate [How to define a sociolinguistic minority: From sign languages to planned languages]. In G. Agresti \& J. G. Turi (Eds.), Atti del primo congresso mondiale dei diritti linguistici [Proceedings of the first world congress on language rights] (pp. 195-222). Rome: Aracne.

Bonfiglio, T. P. (2010). Mother tongues and nations: The invention of the native speaker. New York, NY: De Gruyter Mouton.

Bonfiglio, T. P. (2013). Inventing the native speaker. Critical Multilingualism Studies, 1(2), 29-58.

Caligaris, I. (2016). Una lingua per tutti, una lingua di nessun Paese: Una ricerca sul campo sulle identità esperantiste [One language for all, one language belonging to no country: A fieldwork on Esperantists' identities]. Roma: Aracne.

Calvet, L. J. (2006). Towards an ecology of world languages. London: Polity.

Ceberio Berger, K., Gurrutxaga Hernaiz, A., Soria, C., Russo, I., \& Quochi, V. (2018). How to use the digital language vitality scale (DLDP Project Report). The Digital Language Diversity Project. Retrieved from http://www.dldp.eu/sites/default/files/documents/ DLDP_Digital-Language-Vitality-Scale.pdf

Corsetti, R. (1996). A mother tongue spoken mainly by fathers. Language Problems \& Language Planning, 20(3), 263-282.

Crystal, D. (2004). The language revolution. Cambridge: Polity Press.

Crystal, D. (2008). Txting. The gr8 deb8. Oxford: Oxford University Press.

Directorate-General for Communication. (2012). Special Eurobarometer 286, Europeans and their languages. Brussels: European Commission. Retrieved from https://ec.europa.eu/commfrontoffice/ publicopinion/archives/ebs/ebs_386_en.pdf
Fiedler, S. (2006). Standardization and self-regulation in an international speech community: The case of Esperanto. International Journal of the Sociology of Language, 177, 67-90.

Fiedler, S. (2012). The Esperanto denaskulo: The status of the native speaker of Esperanto within and beyond the planned language community. Language Problems \& Language Planning, 36(1), 69-84.

Floridi, L. (2015). The onlife manifesto. In L. Floridi (Ed.), The onlife manifesto: Being human in a hyperconnected era (pp. 7-13). Cham: Springer.

Garvía, R. (2015). Esperanto and its rivals: The struggle for an international language. Philadelphia, PA: University of Pennsylvania Press.

Gledhill, C. (2000). The grammar of Esperanto: $A$ corpus-based description (2nd ed.). Munich: Lincom Europa.

Gobbo, F. (2015). Transnational communication in a 'glocalized' world: In search of balanced multilingualism. Język, Komunikacja, Informacja, 10, 196-208.

Gobbo, F. (2017). Beyond the nation-state? The ideology of the Esperanto movement between neutralism and multilingualism. Social Inclusion, 5(4), 38-47.

Gobbo, F., \& Alcalde, J. (2016). Towards a tool to analyze linguistic justice: Essential interdisciplinary parameters. Paper presented at the conference JDL2016/GDL2016, Teramo, Italy.

Grin, F., Conceição, M. C., Kraus, P. A., Marácz, L. K., Ozolina, Ž., Pokorn, N., \& Pym, A. (Eds.). (2018). The MIME Vademecum: Mobility and inclusion in multilingual Europe. Grandson: Artgraphic Cavin SA.

Houtkamp, C. (2018). The relevance of motility in language shift research. Language Problems \& Language Planning, 42(1), 1-15.

Houtkamp, C. (2020). Multilingual moves: Language and motility of migrant communities in Europe (Unpublished Doctoral dissertation). University of Amsterdam, Amsterdam, The Netherlands.

Hülmbauer, C. (2009). We don't take the right way: We just take the way that we think you will understand: The shifting relationship between correctness and effectiveness in ELF. In A. Mauranen \& E. Ranta (Eds.), English as a lingua franca: Studies and findings (pp. 323-347). Cambridge: Cambridge Scholars Publishing.

Hülmbauer, C., Böhringer, H., \& Seidlhofer, B. (2008). Introducing English as a lingua franca (ELF): Precursor and partner in intercultural communication. Synergies Europe, 3, 25-36.

Iannàccaro, G., Gobbo, F., \& Dell'Aquila, V. (2018). The assessment of sociolinguistic justice: Parameters and models of analysis. In M. Gazzola, T. Templin, \& B.-A. Wickström (Eds.), Language policy and linguistic justice (pp. 363-391). Cham: Springer.

Jaffe, A. (2015). Defining the new speaker: Theoretical perspectives and learner trajectories. International Journal of the Sociology of Language, 231, 21-44.

Jenkins, J. (2006). Points of view and blind spots: ELF 
and SLA. International Journal of Applied Linguistics, 16(2), 137-162.

Jenkins, J. (2014). English as a lingua franca in the international university: The politics of academic English language policy. Oxford: Routledge.

Jenkins, J., Cogo, A., \& Dewey, M. (2011). Review of developments in research into English as a lingua franca. Language Teaching, 44(3), 281-315.

Kachru, B. (1992). The other tongue. Urbana, IL: University of Illinois Press.

Kraus, P. (2012). The politics of complex diversity: A European perspective. Ethnicities, 12(1), 3-25.

Leigh, I. W., \& O'Brien, C. A. (2019). Deaf identities: Exploring new frontiers. Oxford: Oxford University Press.

Lindstedt, J. (2009). Esperanto: An East European contact language? In C. Voß \& A. Nagórko (Eds.), Die Europäizität der Slawia oder dies Slawizität Europas. Ein Beitrag der kultur- und sprachrelativistischen Linguistik [About the Europeanity of Slavia or the European Slavichood. A contribution linguistic and cultural relativity] (pp. 125-134). Munich: Otto Sagner.

Lindstedt, J. (2010). Esperanto as a family language. In F. Dervin (Ed.), Lingua francas: La véhicularité linguistique pour vivre, travailler et étudier [Linguas francas: Vehicular languages to live, travel and study abroad] (pp. 69-80). Paris: L'Harmattan.

Lussault, M. (2017). Hyper-lieux: Les Nouvelles géographies de la mondialisation [Hyper-places: The new maps of globalization]. Paris: Le Seuil.

Marácz, L. K. (2014). On norms and linguistic categories in linguistic diversity management. Język, Komunikacja, Informacja, 9, 9-26.

Marácz, L. K. (2018). Why should we combine different communication strategies? In F. Grin, M. C. Conceição, P. A. Kraus, L. K. Marácz, Ž. Ozoliṇa, N. Pokorn, \& A. Pym (Eds.), The MIME Vademecum: Mobility and inclusion in multilingual Europe (pp. 102-103). Grandson: Artgraphic Cavin SA.

Marcialis, N. (2011). Le fonti slave dell'esperanto [The influence of Slavic languages in Esperanto]. Studi
Slavistici, 7, 327-341.

Myhill, J. (2006). Language, religion and national identity in Europe and the Middle East: A historical study. Amsterdam: John Benjamins.

O’Rourke, B., Pujolar, J., \& Ramallo, F. (2015). New speakers of minority languages: The challenging opportunity: Foreword. International Journal of the Sociology of Language, 231, 1-20.

Pennycook, A. (2017). The cultural politics of English as an international language. London: Routledge.

Phillipson, R. (1992). Linguistic imperialism. Oxford: Oxford University Press.

Seidlhofer, B. (2009). Orientations in ELF research: Form and function. In C. Mauranen \& E. Ranta (Eds.), English as a lingua franca: Studies and findings (pp. 37-60). Cambridge: Cambridge Scholars Publishing.

Seidlhofer, B. (2011). Understanding English as a lingua franca. Oxford: Oxford University Press.

Seidlhofer, B., Breiteneder, A., \& Pitzl, M. L. (2006). English as a lingua franca in Europe: Challenges for applied linguistics. Annual Review of Applied Linguistics, 26, 3-34.

Selinker, L. (1972). Interlanguage. International Review of Applied Linguistics in Language Teaching, 10(3), 209-230.

Snoddon, K., \& De Meulder, M. (2020). Introduction: Ideologies in sign language vitality and revitalization. Language \& Communication, 74, 154-163.

Sorace, A. (2004). Native language attrition and developmental instability at the syntax-discourse interface: Data, interpretations and methods. Bilingualism: Language and Cognition, 7(2), 1-3.

Soria, C. (2016). What is digital language diversity and why should we care? In J. Cru (Ed.), Digital media and language revitalization (pp. 13-28). Barcelona: Linguapax Review.

Steger, M. B. (2003). Globalization: A very short introduction. Oxford: Oxford University Press.

Zamenhof, L. L. (1905). Fundamento de Esperanto. Paris: Hachette.

\section{About the Authors}

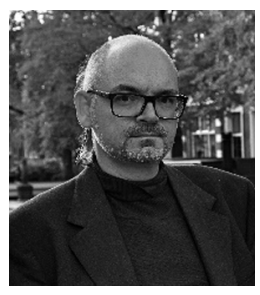

Federico Gobbo is Full Professor at University of Amsterdam. He is Vice-Chairing the EU funded project LITHME (Language in the Human-Machine Era). He has participated in various research projects and worked in various universities in Italy, the Netherlands and China. His research interests include sociolinguistics, interlinguistics, constructive linguistics and philosophy of information. The Esperanto phenomenon is one of his main research interests, and he has published research results about it since 1998.

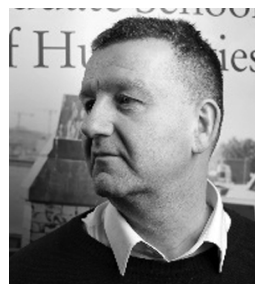

László Marácz has defended his PhD dissertation in General Linguistics at the University of Groningen in 1989. Since 1992, he is affiliated as a Senior Lecturer to the Department of European Studies of the University of Amsterdam. In 2015, László Marácz has been awarded the title of Honorary Professor at the L. N. Gumilyov Eurasian National University in Nur-Sultan, Kazakhstan. He has been Vice-Coordinator of the MIME-consortium that won the European FP7-tender in 2013 on the "Multilingual Challenge for the European Citizen." 